\title{
Moderasi Beragama dalam Ruang Digital: Studi Pengarusutamaan Moderasi Beragama di Perguruan Tinggi Keagamaan Islam Negeri
}

\section{Religious Moderation in The Digital Space: Case Study of Mainstreaming Religious Moderation among Islamic Higher Education Institutions}

\author{
Wildani Hefni \\ Institut Agama Islam Negeri (IAIN) Jember \\ email: wildani91@gmail.com \\ Artikel diterima 17 Maret 2020, diseleksi 20 Mei 2020, \\ dan disetujui 05 Juli 2020
}

Abstrak: Artikel ini ditulis sebagai catatan awal tentang pengarusutamaan moderasi beragama dalam ranah digital untuk menyuarakan narasi keagamaan yang moderat dan toleran. Dunia digital menyediakan prasmanan narasi keagamaan yang bebas akses dan kerapkali dimanfaatkan oleh kelompok tertentu untuk menyuburkan konflik dan menghidupkan politik identitas yang ditandai dengan pudarnya afiliasi terhadap lembaga kegamaan, bergesernya otoritas keagamaan, menguatnya individualisme, dan perubahan dari pluralisme menjadi tribalisme. Pengarusutamaan moderasi beragama di ruang digital menemukan momentumnya. Perguruan Tinggi Keagamaan Islam sebagai laboratorium perdamaian kemudian menguatkan konten-konten moderasi beragama melalui ruang digital sebagai penyeimbang dari arus informasi yang deras di ruang media sosial. Penyeimbang yang dimaksud adalah kontra narasi untuk melahirkan framing beragama yang substantif dan esensial yaitu moderat dan toleran. 
Abstract:This article aims to become a preliminary record about mainstreaming religious moderation in the digital space to spread moderation and tolerant values in religious understanding. The digital world provides a buffet of religious narratives that are free of access and often used by certain groups to foster conflict and revive identity politics marked by fading affiliation with religious institutions, shifting religious authority, strengthening individualism, and changing from pluralism to tribalism. The mainstreaming of religious moderation in the digital space is a must to deal with. Islamic higher education institutions should strengthen religious moderation content through digital space as a counter-narrative. It means giving a religious framing which is substantive and essential that is being moderate and tolerant.

Keywords: Religious Moderation, Digital Space, Islamic Higher Education

\section{A. Pendahuluan}

Kementerian Agama Republik Indonesia menetapkan tahun 2019 sebagai "Tahun Moderasi Beragama". Moderasi beragama dijadikan jargon serta nafas dalam setiap program dan kebijakan yang dibuat oleh Kementerian Agama. Dalam setiap kegiatan yang dilaksanakan, institusi ini berupaya untuk menempatkan diri sebagai institusi penengah (moderasi) di tengah keragaman dan tekanan arus disrupsi yang berdampak pada aspek kehidupan keagamaan dan kebangsaan.

Moderasi beragama yang dimaksudkan dalam konteks ini adalah membawa masyarakat dalam pemahaman yang moderat, tidak ekstrim dalam beragama, dan juga tidak mendewakan rasio yang berpikir bebas tanpa batas. ${ }^{1}$ Moderasi beragama didiskusikan, dilafalkan, diejewantahkan, dan digaungkan sebagai framing dalam mengelola kehidupan masyarakat Indonesia yang mutikultural. Kebutuhan terhadap narasi keagamaan yang moderat tidak hanya menjadi kebutuhan personal atau kelembagaan, melainkan secara umum bagi 
warga dunia, terutama di tengah perkembangan teknologi informasi dalam menghadapi kapitalisme global dan politik percepatan yang disebut dengan era digital.

Di dalam ruang digital yang dikendalikan oleh kecepatan elektronik, eksistensi manusia mengalami perubahan mendasar dari sebuah bentuk tubuh yang bergerak di dalam ruang, menjadi sebentuk tubuh yang diam di tempat dan hanya mampu menyerap setiap informasi yang lewat melalui simulasi elektronik. ${ }^{2}$ Ruang digital kemudian menjadi arena kontestasi dan kompetisi.

Pada titik inilah, ruang-ruang digital dimanfaatkan oleh kelompok tertentu untuk menyuburkan konflik dan menghidupkan politikidentitas. Ruang digital itu kini lebih condong didominasi nilai keagamaan yang menjurus kepada eksklusivitas. Tidak hanya itu, ajaran-ajaran agama dipertentangkan dengan kebijakan-kebijakan negara. Kondisi demikian sangat mengkhawatirkan karena dapat menggeser otoritas keagamaan serta menumbuhkan peremajaan Ulama. Bagaimana tidak, otoritas keagamaan tidak lagi dipegang oleh para Ulama yang otoritatif dan kredibel.

Dalam teori Religious-Social Shaping of Technology yang diperkenalkan oleh Heidi Campbell dalam bukunya When Religion Meets New Media $(2010)^{3}$, dijelaskan bahwa dampak era digital terhadap cara beragama masyarakat, di antaranya yang paling terasa adalah pudarnya afiliasi terhadap lembaga keagamaan, bergesernya otoritas keagamaan, menguatnya individualisme, dan perubahan dari pluralisme menjadi tribalisme.

Sementara narasi dan kajian keagamaan merupakan arena kompetitif yang memiliki potensi besar untuk diproduksi oleh kelompok tertentu guna menyebarluaskan ide, gagasan, dan simbol keagamaan kepada publik. Kajian keagamaan menjadi arena basah yang mudah dipermainkan dan dinarasikan sesuai dengan keinginan subyektif semata. ${ }^{4}$ Kondisi demikian disadari bahwa masyarakat beragama saat ini 
sebatas pada simbol dan masih jauh dari nilai-nilai substansial.

Ironisnya, gerakan kelompok garis keras (hard liners) yang mempertontonkan narasi keagamaan secara agresif dan emosional, justru mendapat simpati di sebagian hati umat Islam. Riuh simpati ini didapatkan dari ruang digital yang tingkat penyebarannya begitu massif dan mudah. Terlebih, di tahun politik dimana sentimen keagamaan kerap dimanfaatkan untuk menebar kebencian sesama anak bangsa melalui media digital. Media telah menjadi komoditas baru dalam menyebarkan ideologi keagamaan tertentu dan kepentingan tertentu sebagai bentuk perlawanan atas organisasi keagamaan yang tidak memiliki kesamaan pemahaman dan juga sebagai bentuk pembelaan dari golongannya sendiri. $^{5}$

Di tengah fenomena yang mengkhawatirkan ini, Kementerian Agama melihat perlunya cara beragama yang inklusif dan toleran untuk bisa merebut panggung ruang digital dengan menguatkan moderasi beragama di tengah-tengah masyarakat, termasuk di lingkungan civitas akademika Perguruan Tinggi Keagamaan Islam di seluruh Indonesia. Dalam konteks ini, Kementerian Agama melalui Direktorat Jenderal Pendidikan Islam mengeluarkan Surat Edaran tanggal 29 Oktober 2019 yang ditujukan kepada seluruh Rektor dan Ketua Perguruan Tinggi Keagamaan Islam Negeri (PTKIN) agar mendirikan dan menyelenggarakan Rumah Moderasi Beragama. Dalam edaran tersebut dijelaskan bahwa Kementerian Agama memiliki komitmen untuk menjadikan Moderasi Beragama sebagai bagian dari landasan berpikir, bersikap, dan rumusan kebijakan serta program di seluruh stakeholder Kementerian Agama, termasuk di PTKIN. Rumah moderasi beragama diminta menjadi pusat edukasi, pendampingan, pengaduan, dan penguatan wacana dan gerakan moderasi beragama di lingkungan PTKIN. ${ }^{6}$

Dalam bentuk implementasinya, masing-masing PTKIN kemudian mendirikan Rumah Moderasi dengan program kerja yang berbedabeda namun satu visi misi untuk membuat ruang keagamaan yang mengedepankan adab (civilized). Beberapa PTKIN mengambil dan 
merebut ruang publik digital dan media sosial sebagai wadah dan wahana pengayaan wacana moderasi beragama untuk terus disosialisasikan ke publik. Penyebaran ide melalui konten-konten tertentu seperti video, meme, publikasi karya, tulisan artikel dan opini, semuanya diproduksi dan disebarkan kepada civitas akademik dan umum.

Artikel ini mendedah bagaimana transformasi dan transmisi moderasi beragama disalurkan dalam ranah digital sebagai ruang kontestasi merebut narasi keagamaan yang moderat dan toleran. Selain itu, artikel ini berupaya memahami kecerdasan digital yang berarti kecerdasan dalam memanfaatkan informasi, media dan teknologi untuk keperluan menjaga moderasi beragama yang dihadapkan dengan "prasmanan narasi keagamaan". Sebagaimana diketahui secara umum, banyak sekali persoalan gagap digital yang menjangkit umat beragama yang kemudian berdampak mudahnya seseorang menyebarkan berita bohong yang dapat mengancam integritas bangsa. Sebaliknya, juga ada ahli digital yang memanfaatkan kecerdasannya untuk menyebar berita bohong.

Jenis data yang digunakan dalam penelitian ini adalah ungkapanungkapan atau pernyataan, baik tertulis maupun lisan. Sumber data utama berupa dokumen berita dan teks narasi penguatan moderasi beragama di beberapa Perguruan Tinggi Keagamaan Islam Negeri berupa program, flyer, dan dokumen-dokumen kajian virtual. Metode pengumpulan data yang digunakan adalah library research dengan teknik note-taking. Adapun teknis analisis data yang digunakan adalah deskriptif-analitik.

\section{B. Pembahasan dan Hasil}

Upaya pengarusutamaan (mainstreaming) moderasi beragama secara terus menerus melalui dialog dan saluran kanal ruang digital sangatlah penting agar Indonesia sebagai negara dengan penduduk muslim terbesar di dunia, bisa menjadi laboratorium perdamaian. Sebagaimana diketahui, Indonesia merupakan negara plural dan multikultural dengan 
pelbagai jenis suku, agama, bahasa, ras, dan pelbagai perbedaan lainnya. Namun, keberagaman itu tetap membawa masyarakat dalam kehidupan yang harmonis-berdampingan.

Seringkali konflik dan perpecahan lahir dari kesalahpamahan yang mengalir deras melalui ruang digital. Lebih dari itu, ruang digital dimanfaatkan dengan sengaja untuk membuat narasi yang saling menjatuhkan. Padahal, secara substansi, semua ajaran agama menginginkan hidup damai, moderat, menjaga kerukunan dan welas asih. Moderasi beragama menjadi senjata untuk menjaga kebersamaan dalam keberagaman. Sebelum masuk pada pembahasan moderasi beragama dalam ruang digital, pada awal artikel ini akan dijelaskan kajian konseptual terkait moderasi beragama.

\section{Kajian Konseptual Moderasi Beragama}

Kata "moderasi" berasal dari bahasa latin "moderatio" yang memiliki arti ke-sedang-an (tidak berlebihan dan tidak kekurangan). Dalam Kamus Besar Bahasa Indonesia (KBBI), moderasi dimaknai dengan dua pengertian yaitu pengurangan kekerasan dan penghindaran keekstreman. Dalam bahasa Inggris, kata moderation sering digunakan dalam artian average (rata-rata), core (inti), standart (baku), atau non-aligned (tidak berpihak). Dari beberapa kata yang disebutkan, moderat berarti mengedepankan keseimbangan dalam hal keyakinan moral, watak, baik ketika memperlakukan orang lain secara individu ataupun berhadapan dengan institusi negara. Sedangkan dalam bahasa arab, moderasi dikenal dengan kata wasath atau wasathiyah, yang memiliki padanan kata tawassuth (tengah-tengah), i'tidal (adil) dan tawazun (berimbang). Antonim dari kata wasath adalah tatharruf (berlebihan), yang dalam bahasa Inggris disebut dengan kata extreme, radical, dan excessive. ${ }^{7}$

Wasathiyah atau moderasi beragama sejatinya adalah esensi dan substansi dari ajaran agama yang sama sekali tidak berlebihan, baik dalam cara pandang atau bersikap. Prinsip moderasi beragama (wasathiyah) adalah sikap dan cara pandang yang penuh dengan nilai- 
nilai keseimbangan (balance) dan adil (justice). ${ }^{8}$ Dengan konsep demikian, dapat dipahami bahwa seseorang dalam beragama tidak boleh ekstrim pada pandangannya, melainkan harus selalu mencari titik temu.

Dengan demikian, moderasi beragama dapat dipahami sebagai cara pandang, sikap dan perilaku yang berada di posisi tengah tanpa berlebih-lebihan dalam beragama yaitu tidak ekstrem. Tidak berlebihan yang dimaksud disini adalah menempatkan satu pemahaman pada tingkat kebijaksanaan yang tinggi dengan memperhatikan pada teks agama, konstitusi negara, kearifan lokal, dan konsensus bersama. Hal itu Saat moderasi beragama dijunjung dan diberlakukan dalam setiap nafas kehidupan, setidaknya akan mengurangi prasangka yang kemudian melahirkan konflik dan pertentangan.

Dalam buku Moderasi Beragama yang ditulis oleh Tim Balitbang Kemenag RI, dijelaskan bahwa moderasi bukan hanya diajarkan oleh Islam, tapi juga agama lain. Pada prinsipnya, sikap adil dan berimbang yang melekat pada prinsip moderasi beragama dapat membentuk seseorang untuk memiliki tiga karakter utama yaitu kebijaksanaan (wisdom), ketulusan (purity), dan keberanian (courage). Dengan kata lain, sikap moderat dalam beragama, selalu memilih jalan tengah, akan lebih mudah diwujudkan apabila seseorang memiliki keluasan pengetahuan agama yang memadai sehingga dapat bersikap bijak, tahan godaan sehingga bisa bersikap tulus tanpa beban, serta tidak egois dengan tafsir kebenarannya sendiri sehingga berani mengakui tafsir kebenaran orang lain. ${ }^{9}$

Moderasi beragama dalam konteks ini merupakan tangga awal untuk menumbuhkan toleransi dan persatuan antara satu kelompok dengan kelompok yang lain, antara satu pemeluk agama dengan pemeluk agama lain, dan antar satu komunitas dengan komunitas yang lain. Dengan arti bahwa menolak ekstremisme dan liberalisme adalah jalan tengah yang yang cukup bijak guna menciptakan kerukunan. Moderasi beragama adalah memperlakukan orang lain secara terhormat dengan menerima 
perbedaan sebagai ciri dari keragaman. Moderasi beragama sejatinya merupakan implementasi dari nilai-nilai toleransi (tasamuh).

Selan itu, konsep moderasi beragama sangat menjunjung nilai-nilai egaliter (musawah) dengan tidak berpandangan diskriminatif terhadap yang lain. Perbedaan keyakinan, tradisi, agama, bahasa, dan suku, serta antar golongan tidak menjadi penyebab tersulutnya sumbu kesewenangwenangan yang dapat memberangus tali persaudaraan. Dalam konteks ini, moderasi beragama dapat dipahami sebagai jalan tengah untuk menciptakan kehidupan yang damai dan harmoni, terlebih di negara yang multikultural ini. ${ }^{10}$

\section{Penguatan Moderasi Beragama di Perguruan Tinggi Keagamaan Islam}

Moderasi beragama menemukan relevansinya untuk dikokohkan di atas dasar filosofi universal dalam konstruk pengembangan keilmuan di Perguruan Tinggi Keagamaan Islam Negeri (PTKIN). Hal ini sangat penting selain sebagai sarana tepat guna menyebarkan sensitivitas civitas akademika pada nalar perbedaan, namun juga sebagai strategi penguatan intelektualisme moderat agar tidak mudah menyalahkan pendapat yang berbeda. ${ }^{11}$

Direktur Jenderal Pendidikan Islam Kementerian Agama, Kamaruddin Amin dalam setiap kesempatan selalu menyampaikan bahwa moderasi beragama menjadi kontra narasi dari pemahaman-pemahaman ekslusif yang dikembangkan oleh keleompok tertentu. Karena itu, edaran yang dikeluarkan oleh Kementerian Agama berupa pendirian Rumah Moderasi yang diharapkan menjadi lokomotif gerakan moderasi beragama yang menyampaikan pesan agama yang damai dan toleran, sangat relevan untuk menjadi wadah kontra narasi pemahaman keagamaan yang rigid.

Dalam konteks ini, Perguruan Tinggi Keagamaan Islam menjadi laboratorium penyemaian nilai-nilai moderat. Dalam sejarah perkembangannya, PTKIN didirikan sebagai kehendak untuk menciptakan model kajian dan pemahaman Islam yang inklusif, 
akademis, sosiologis, historis, dan filosofis berbasis pada kajian teks dan analisis sosial yang melihat agama sebagai kenyataan kemasyarakatan. Dampak dari hal tersebut, wacana studi keislaman di perguruan tinggi telah diwarnai oleh nuansa akademis. Implikasinya, wacana tentang narasi keagamaan di Indonesia banyak lahir dari dunia akademik Perguruan Tinggi Keagamaan Islam. Nalar intelektualisme inklusif dan kritis inilah yang menjadi kekuatan besar untuk menguatkan tradisi akademik yang toleran. ${ }^{12}$

Hal itu semua dapat terwujud bila semua komponen masyarakat termasuk civitas akademika bersikap moderat baik di ruang nyata serta ruang maya. Rumah moderasi beragama di Perguruan Tinggi Keagamaan Islam menjadi wadah untuk menyuarakan (speak up) dengan komitmen moderasi beragama dengan kajian, riset, publikasi, serta pendampingan masyarakat.

Para pimpinan Perguruan Tinggi Keagamaan Islam telah meluncurkan buku yang berjudul Moderasi Beragama: Dari Indonesia untuk Dunia (2019). Dalam buku tersebut dipaparkan beberapa langkah strategis penguatan moderasi beragama di Perguruan Tinggi Keagamaan Islam. Pertama, pengarusutamaan moderasi beragama diimplementasikan dalam segala turunan kebijakan Perguruan Tinggi Keagamaan Islam dan diwujudkan dengan pengembangan kajian dan tradisi akademik yang kritis dan menghargai kelompok atau pendapatlain. Dalam konteksini, penyematan kurikulum yang di dalamnya terdapat subjek-subjek ideologis harus selalu dipicu sebagai basis penguatan. Subjek ideologis dapat dibaca misalnya seperti pendidikan Pancasila dan Kewargaan. Secara spesifik, Perguruan Tinggi Keagamaan Islam dapat menerapkan kebijakan dan pelembagaan nilai-nilai kewargaan dalam budaya pendidikan.

Kedua, menjadikan Perguruan Tinggi Keagamaan Islam sebagai wadah dan tempat penyemaian nilai-nilai kemanusiaan, nilai-nilai kerukunan beragama, dan moderasi beragama. Persoalan ini sangat mendesak saat pendidikan Islam kembali menghadapi tantangan serius yang menjamur 
dalam konstruk pemahaman sektarian dan juga Islam transnasional. Fefomena ini muncul di Perguruan Tinggi Keagamaan Islam dengan gejala Islamisasi yang dibawa oleh sekelompok mahasiswa melalui forum-forum tarbiyah dan pengkaderan. Ketiga, mengembangkan literasi keagamaan (religious literacy) dan pendidikan lintas iman (interfaith education). ${ }^{13}$

Dalam peningkatan literasi keagamaan ini, Perguruan Tinggi Keagamaan Islam memainkan perannya yang signifikan untuk menyuarakan moderasi beragama melalui ruang digital. Di zaman serba instan dan pragmatis saat ini, pemahaman masyarakat terhadap narasi keagamaan yang bertebaran cenderung mengalami bias dan kontraproduktif. Ada yang terlalu tekstual dalam memahami ayat-ayat suci disertai fanatisme berlebihan sehingga mengarah pada ekslusivisme, ekstremisme, bahkan terorisme. Ada juga yang melampaui batas (beyond boundaries) hingga kebablasan menafsirkan kitab suci. Ada pula yang mempermainkan pesan-pesan Tuhan menjadi pesan pribadi yang sarat kepentingan. Konsekuensi logis yang terjadi adalah rentannya konflik kepentingan yang dapat mengoyak tali harmoni kehidupan keagamaan. Dalam konteks ini, moderasi beragama menjadi keharusan untuk dapat diviralkan, disebarluaskan, disosialisasikan, dan dilafalkan dalam ruangruang digital untuk diimplementasikan dalam tataran praktis kehidupan sehari-hari.

Sejauh ini, beberapa Perguruan Tinggi Keagamaan Islam Negeri (PTKIN) yang telah melakukan transformasi pengarusutamaan dan penguatan moderasi beragama melalui ruang-ruang digital antara lain Universitas Islam Negeri (UIN) Syarif Hidayatullah Jakarta, Universitas Islam Negeri (UIN) Sunan Gunung Djati Bandung, Universitas Islam Negeri (UIN) Walisongo Semarang, Universitas Islam Negeri (UIN) Raden Intan Lampung, Institut Agama Islam Negeri (IAIN) Kudus, Institut Agama Islam Negeri (IAIN) Metro, Institut Agama Islam Negeri (IAIN) Jember, dan perguruan tinggi lainnya yang juga telah mendirikan Rumah Moderasi. Data tersebut dapat dilihat dari kajian-kajian virtual 
yang diselenggarakan oleh Rumah Moderasi Beragama di lingkungan PTKIN. Hal itu antara lain Pusat Kajian Moderasi Beragama (PKMB) UIN Raden Intan Lampung yang menggelar kajian virtual menggunakan media zoom, facebook, dan youtube untuk membahas pelbagai strategi menumbuhkan sikap moderasi beragama di perguruan tinggi. Sama halnya dengan Rumah Moderasi Beragama IAIN Jember, juga menggelar Webinar series yang membahas tentang penguatan wacana keagamaan moderat dalam ruang digital.

\section{Narasi Keagamaan di Abad Cyberspace}

Kemajuan teknologi informasi yang dikenal dengan abad virtual dewasa ini telah menggiring konsep-konsep sosial seperti integrasi, kesatuan, persatuan, dan solidaritas dalam batas-batas yang kian mengkhawatirkan. Percaturan sosial-politik saat ini tidak lagi diikat dalam satu ideologi politik tertentu, melainkan individu-individu yang satu sama lain saling berlomba dalam sebuah arena kontestasi. Realitas sosial tenggelam dalam hutan rimba virtualitas. Inilah yang oleh Yasraf Amir Piliang disebut dengan abad cyberspace. ${ }^{14}$

Cyberspace adalah sebuah dunia komunikasi berbasis komputer untuk melipat ruang dan waktu dan menawarkan realitas baru berbentuk virtual. Dalam bahasa yang berbeda, cyberspace juga dapat diartikan sebagai suatu imaginary location ${ }^{15}$ (tempat aktivitas elektronik dilakukan) guna meringkas dan memampatkan ruang-waktu (time-space compression). Pamadatan ini memiliki tujuan pasti untuk menghilangkan hambatan ruang (spatial barriers) menggunakan kecanggihan teknologi. Proses akhir yang dapat dihasilkan dari pemadatan ini adalah terjadinya percepatan dunia kehidupan. ${ }^{16}$

Jaringan informasi menjadi bersifat transparan dan virtual. Hal ini semakin terbuka luas karena tidak terdapat lagi kategori-kategori moral yang mengikatnya. Tidak ada pula ukuran-ukuran nilai yang membatasinya. Akibatnya, batasan, aturan, ikatan dan kode-kode moral yang selama ini mengendalikan setiap tindakan di dunia nyata, kini tak 
dapat lagi sepenuhnya berlaku. Ketika semua itu berputar dalam ranah digital dan dalam lintas sirkuit global, maka hukum yang mengatur masyarakat bukan lagi hukum kemajuan, melainkan hukum orbit. ${ }^{17}$ Dalam hukum orbit, segala sesuatu yang diviralkan, dengan mudah dan dalam waktu yang sangat cepat berputar sekaligus berpindah secara global.

Dalam konteks ini, penyebaran narasi keagamaan dengan mudah diorbitkan dalam hitungan detik yang menyebar dari satu tempat ke tempat lain, dan dari dari satu kanal informasi ke kanal yang lain. Perputaran itu terus berlanjut dari satu teritorial ke teritorial lain, dan dari satu kebudayaan ke kebudayan yang lain, dalam wujud virtual yang digiring oleh orbit party-line.

Dunia digital saat ini telah memproduksi ide dan gagasan sehingga membentuk sebuah pemikiran yang tertanam dalam pemahaman masyarakat. Pengalaman keagamaan yang bersifat personal, fatwa-fatwa yang tak berdasar, serta pengetahuan yang tidak jelas sanadnya, terus diciptakan sedemikian rupa untuk menggiring masyarakat. Otoritas keagamaan mengalami pergeseran berkat kolonialisasi informasi dan pelipatan kesadaran. Sebelumnya, otoritas keagamaan hanya dimiliki oleh para Ulama, ustadz, mursyid, guru agama, dan pemerintah melalui Kementerian Agama. Namun, saat ini otoritas keagamaan direngkuh oleh media baru yang tampak impersonal dan berbasis pada jejaring informasi. Setiap orang dengan mudah mengakses pengetahuan menurut selera dan kebutuhan masing-masing. ${ }^{18}$ Narasi keagamaan disediakan seperti menu prasmanan yang bebas diambil dalam format yang tersedia.

Kondisi masyarakat kita saat ini yang tengah tenggelam dalam ekstasi komunikasi virtual dimanfaatkan oleh kelompok tertentu untuk menawarkan ide, pendapat, fatwa kepada orang lain tanpa batas. Kondisi ini telah menggeser pemahamaman moderat dalam Islam keaarah non-mainstream yang cenderung ekslusif, keras, rigid, dan bahkan memonopoli kebenaran. Narasi keagamaan yang diciptakan telah menggeser otoritas Ulama sebagai rujukan dalam memahami teks 
suci yang kemudian melahirkan fabrikasi dan distorsi pemahaman. ${ }^{19}$

Dunia digital kemudian memiliki dampak negatif dalam struktur dan narasi keagamaan. Pelbagai kelompok tertentu melahirkan kontenkonten keagamaan yang bertumpu pada pemahaman tunggal sehingga memicu tumbuhnya politik identitas dan konflik ketegangan. Dalam konteks ini, dunia digital (cyberspace) dimanfaatkan untuk melahirkan proliferasi misinformasi dan disinformasi oleh sekolompok orang yang mengatasnamakan agama dalam narasi kontennya. Bahkan, dunia digital digunakan sebagai wadah untuk memecah persatuan umat oleh kelompok tertentu yang merasa tidak puas dalam kontestasi tertentu dan kemudian mengambil kendali atas otoritas sumber agama melalui kanal-kanal digital. ${ }^{20}$

Disrupsi informasi dan semburan politik identitas mengemuka dalam ruang-ruang digital. Konsumsi, selera, dan makna yang dihasilkan oleh dunia virtual mengantarkan pada perubahan cara berpikir, perumusan fatwa-fatwa, ekspresi keagamaan, dan bahkan landasan berkeyakinan. Kehidupan keagamaan hari ini dihadapkan pada kecenderungan yang mengeras ditandai dengan hilangnya esensi dan substansi dari agama itu sendiri. Dampaknya, imajinasi kebangsaan terkoyak dalam ruang virtualitas yang dikemas dalam balutan fanatisme.

Setidaknya ada tiga permasalahan mendasar terkait dengan narasi keagamaan yang diciptakan oleh kelompok tertentu untuk memancing sentimen antar kelompok. ${ }^{21}$ Pertama, problem pemahaman agama. Media elektronik sangat terbuka dan bisa diakses oleh masyarakat umum tanpa ada batasan. Ruang digital menyediakan pelbagai konten termasuk konten ceramah dan narasi keagamaan yang tanpa kontrol. Tidak jarang, narasi keagamaan di media digital kemudian melahirkan pemahaman yang bias dan cenderung membenarkan satu kelompok dan menyalahkan yang lain (others). Dari titik inilah, kelompok Muslim lahir dengan fanatisme keagamaan yang obsolut, ekslusif dan tidak permisif terhadap keragaman lalu mengkafirkan yang lain. Padahal, mereka mendapatkan pengetahuan dari ruang-ruang digital yang bebas dan liar. 
Realitas demikian diperkeruh dengan fenomena post-truth (pasca kebenaran) yang berpotensi mempertajam polarisasi di masyarakat dengan ditandai semakin viralnya pemahaman yang tendensius mengusung sentimen agama, ras dan kelompok kepentingan yang dapat menjadi tantangan sekaligus hambatan dalam memacu keberlanjutan pembangunan nasional. ${ }^{22}$

Kedua, pergeseran otoritas keagamaan. Otoritas keagamaan adalah persoalan yang selalu diperdebatkan. Namun, dalam konteks perkembangan dunia teknologi yang tak dapat dibendung, seringkali otoritas keagamaan bergeser dari personal kepada impersonal.Akibatnya, kehidupan keagamaan mengeras berdasar keyakinan yang dimiliki masing-masing tanpa rambu-rambu. Dalam melihat sisi perbedaan, yang ada hanyalah fanatisme yang kemudian melahirkan intoleransi.

Ketiga, pola pikir dan perilaku masyarakat yang berlebihan. Kegandurungan terhadap teknologi telah membawa masyarakat dalam ekstasi konsumerisme keagamaan. Ilmu pengetahuan yang diserap secara bebas melalui kanal-kanal informasi digital menjadi sandaran untuk bertindak sesuai dengan yang diperoleh dari media tersebut. Padahal, media baru dengan karakteristiknya yang praktis dan multitasking banyak mereduksi pemahaman agama yang moderat, toleran dan penuh kasih sayang. ${ }^{23}$

Narasi keagamaan yang berkembang dalam perkembangan teknologi komunikasi dan informasi yang kita kenal dengan ruang kanal digital yang sifatnya terbuka, dengan mudah diputarbalikkan dan bahkan didekonstruksi, misalnya informasi yang diviralkan melalui media whatsapp. Internet dengan imajinasi virtualnya yang mengandung pasar bebas nilai nilai (value free market) berhasil digiring pada penyebaran narasi keagamaan yang dangkal, banal dan berputar pada tataran permukaan. Misalnya, dalam ruang digital, orang dapat melakukan perjuangan moral untuk legalisasi kepentingan politik indetitas. Hal ini menjadi tantangan sekaligus halangan dalam upaya mengarusutamakan moderasi beragama dalam ruang-ruang digital. 


\section{Moderasi Beragama sebagai Kontra Narasi}

Teknologi informasi memiliki peran yang sangat vital dalam mempercepat pelipatan ruang dan waktu. Maraknya dunia virtual yang mudah diakses telah mengantarkan masyarakat pada problem paradoksial. Satu sisi, masyarakat sedang dalam semangat tinggi untuk memperbaharui dan mengekpresikan identitas keislaman, namun disatu sisi, pelbagai ruang digital diwarnai oleh narasi keagamaan yang tidak objektif, bahkan cenderung mengandung nilai-nilai fanatisme yang membenci terhadap kelompok lain. Hal inilah yang dikategorikan sebagai siklus Islamisasi yang didorong oleh kebutuhan akan informasi pengetahuan agama. Semakin religius seseorang, maka tentu akan lebih memilih untuk membaca teks-teks keagamaan yang cenderung Islamis, praktis, dan pragmatis. ${ }^{24}$

Dalam konteks ini, pengarusutamaan (mainstreaming) moderasi beragama diruang digital menemukan momentumnya. Pengarusutamaan moderasi beragama yang dilakukan di Perguruan Tinggi Keagamaan Islam di seluruh Indonesia melalui ruang digital bertujuan untuk menjadikan sesuatu yang awalnya berada di pinggiran, hanya diketahui oleh orang dan kelompok terbatas dan bahkan kurang dianggap penting, kemudian digiring ke area tengah agar diketahui publik secara umum, dikonsumsi, dan diimplementasikan. Hal itu dilakukan dengan memanfaatkan ruang digital yang memiliki aneka fungsi, kegunaan, kapasitas, dan potensialitas.

Ruang digital teknologi informasi digunakan dalam pengarusutamaan moderasi beragama sebagai narasi digital (digital narrative) yaitu sebuah narasi keagamaan yang dikemas dalam konten tertentu secara baik dan sistematis dan kemudian disebarluaskan oleh teknologi informasi digital. Narasi digital mampu membentangkan cara kehidupan yang sebelumnya tak pernah terbayangkan, seperti artificial life, networking, dan real time interaction. ${ }^{25}$ Ruang digital teknologi informasi menjadi sebuah wadah (container) penguatan kehidupan yang moderat untuk 
dapat membangun identitas dan makna kehidupan. Karena itu, teknologi informasi menjadi kontra narasi untuk melawan narasi-narasi keagamaan yang memonopoli kebenaran. Heidegger (1971) menyebut teknologi dapat membuka, membentangkan, sekaligus memengaruhi pola dan cara pandang seseorang, walaupun disatu sisi juga sebaliknya, dapat menimbulkan ketakutan, ketidakpuasan, dan pemenjaraan. ${ }^{26}$

Penyebarluasan moderasi beragama melalui ruang digital teknologi informasi dapat menjangkau masyarakat lebih luas dan lebih khusus pada generasi milenial. Perebutan ruang digital menjadi kunci untuk mendominasi narasi-narasi keagamaan dalam ruang media sosial. Ruang digital yang tidak diimbangi dengan narasi-narasi keagamaan yang moderat dan berbasis pada nilai-nilai toleransi akan melahirkan tindakan yang bebas. Kebebasan inilah yang dalam kondisi mutakhir ini melahirkan konflik dan cara pandang yang intoleran.

Perguruan Tinggi Keagamaan Islam sebagai laboratorium perdamaian menyuarakan konten-konten moderasi beragama melalui ruang digital sebagai penyeimbang dari arus informasi yang deras di ruang media sosial. Penyeimbang yang dimaksud disini adalah kontra narasi untuk melahirkan framing beragama yang substantif sesuai dengan ajaran esensi agama yaitu moderat, toleran, dan penuh kasih sayang antar sesama. Hal itu dapat dilakukan dengan suarasuara nyaring di ruang digital menggunakan teknologi informasi. Oleh karena itu, skema teknologi yang mendeterminasi dan mendisiplinkan kehidupan keagamaan menjadi arena kontestasi yang harus direbut dan dikuasai dengan narasi-narasi keagamaan berbasis moderasi beragama. Perguruan Tinggi Keagamaan Islam dalam penyebaran ide dan gagasan moderasi beragama menggunakan beberapa konten misalnya konten di youtube, fanspage Facebook, twitter, Instagram, meme, atau rilis tentang kajian dan riset kerukunan beragama.

Hal ini sejalan dengan konsep yang dijelaskan oleh Mihaly Csikszenthimaly (1993) yang menyatakan bahwa perkembangan 
informasi dunia digital yang disebarluaskan melalui konten-konten tertentu dapat mempengaruhi perkembangan diri. ${ }^{27}$ Csikszenthimaly menggunakan istilah meme untuk menjelaskan unit informasi budaya. Meme diciptakan secara sengaja dan sadar oleh manusia untuk tujuan tertentu. Sekali meme menjadi eksistensi, ia mulai beraksi dan mentransformasikan kesadaran penciptanya dan manusia lainnya yang berhubungan dengannya.

Ketika narasi moderasi beragama diviralkan dalam bentuk meme dengan konten dan pesan tertentu, ia akan menggiring pikiran setiap orang untuk berpikir secara moderat dalam setiap tindakan dan prilaku, yang sebelumnya tidak ada di dalam pikiran seseorang. Maka, meme yang pada awalnya dibentuk oleh pikiran manusia dalam dan diviralkan dalam ruang digital, ia segera mulai membentuk pikiran itu sendiri.

Dalam konteks ini, meme yang memiliki konten moderasi beragama, dengan sendirinya bergerak untuk melakukan pengarusutamaan (mainstreaming) untuk menggiring sebuah wacana atau pikiran yang sebelumnya tidak ada atau sudah ada tapi masih berada dalam wilayah pinggiran. Dalam arti, belum massif diwacanakan atau diperbincangkan. Maka, meme sejatinya hidup secara kultural dengan menggunakan energi manusia melalui tingkah dan laku seperti perhatian, persepsi, pikiran untuk mencipta sebuah energi. Sekali meme diproduksi dan diviralkan, ia akan mengembangbiakkan dirinya untuk mennumbuhkan persepsi. Menurut Yasraf, meme mengkopi dirinya sendiri (replication) untuk tumbuh dan hidup dalam pikiran manusia sebagai tempat hidupnya (host)..$^{28}$

\section{Kesimpulan}

Pengarustamaan moderasi beragama tidak bisa bergerak dirisendiri, namun harus berjalan beriringan untuk mencapai target yang diinginkan. Menjadikan moderasi beragama sebagai framing adalah kata kunci bersama sebagai dasar pengelolaan kehidupan keagamaan 
yang moderat dan toleran di tengah-tengah masyarakat multikultural. Terlebih, perkembangan teknologi menuntut dengan seksama untuk menyuarakan konten yang pas dan sesuai bagi masyarakat digital yang notabene adalah generasi milenial.

Apa yang dilakukan oleh Perguruan Tinggi Keagamaan Islam dalam mengarusutamakan moderasi beragama dalam ruang digital merupakan bentuk kesadaran yang menemukan relevansinya seiring isu-isu keagamaan di media sosial yang beredar luas dengan liar. Kepercayaan terhadap nilai moderasi dan kebersamaan kemudian lenyap dimakan oleh narasi keagamaan yang tendensius dan menonjolkan fanatisme kebenaran.

Di era yang serba terbuka, masyarakat memperoleh pengetahuan keagamaan dengan cara instan dan pragmatis. Sanad keilmuan tidak lagi menjadi kunci dari proses belajar. Siapa yang cepat menyajikan narasi keagamaan, maka akan memperoleh jamaah dengan mudah. Karena itu, pengarusutamaan moderasi beragama yang dilakukan oleh Perguruan Tinggi Keagamaan Islam melalui Rumah Moderasi dengan menyediakan dan menyebarluaskan konten sebagai kontra narasi dari suara-suara sumbing teks keagamaan, dapat menjadi suara penyeimbang, bahkan menjadi suara dominan untuk menggeser pemahaman keagamaan yang bersifat tunggal dan kaku.

Era digital menuntutmasyarakatuntuk berhati-hati agar tak terjerumus dalam kubangan ekstasi konsumerisme keagamaan. Ilmu pengetahuan harus benar-benar dikaji dan diteliti, agar tidak tidak terjerambab dalam kanal-kanal informasi digital yang kemudian menjadi sandaran untuk bertindak sesuai dengan yang diperoleh dari media tersebut. Oleh karena itu, moderasi beragama menjadi basis penguatan paham keagamaan melalui ruang digital yang memiliki karakteristik multitasking untuk mengokohkan pemahaman keagamaan yang moderat, toleran dan penuh kasih sayang. 


\section{Daftar Pustaka}

Ahmadi, Rizqa. 2019. “Kontestasi Atas Otoritas Teks Suci Islam di Era Disrupsi: Bagaimana Kelas Menengah Muslim Indonesia Memperlakukan Hadis Melalui Media Baru", Jurnal Studi Agama dan Masyarakat, Vol. 15, No. 1 https://doi.org/10.23971/jsam. v15i1.1138

Busro. 2019. “Moderasi Islam (Wasatiyyah) di Tengah Pluralisme Agama di Indonesia", Fuaduna: Jurnal Kajian Keagamaan dan Kemasyarakatan, Vol. 3, No. 1.

Campbell, Heidi. 2010. When Religion Meets New Media. London: Routledge.

Dawson, Lorne. 2000. "Researching Religion in Cyberspace: Issues and Strategies" dalam Religion on the Internet: Research Prospects and Promises, Religion and the Social Order, Volume 8, ed Jeffery Hadden dan Douglas Cowan, New York: JAI Press.

Edaran Direktur Jenderal Pendidikan Islam Kementerian Agama RI Nomor B-3663.1/Dj.I/BA.02/10/2019 tentang Rumah Moderasi Beragama tanggal 29 Oktober 2019.

Fuller, Steve. 2018. Post Truth: Knowledge as Power Game. London: Anthem Press.

Harvey, David. 1990. The Condition of Postmodernity: An Inquiry into The Origins of Cultural Change. Cambridge: Blackwell Publisher.

Jinan, Mutohharun. 2013. “Intervensi New Media dan Impersonalitas Otoritas Keagamaan”, Jurnal Komunikasi Islam, Vol. 3, No. 2. https:// doi.org/10.15642/jki.2013.3.2.\%25p

Kamali, Mohammad Hasyim. 2015 The Middle Path of Moderation in Islam: 
The Qur'anic Principle of Wasathiyah. Oxford: Oxford University Press.

Kellerman, Aharon. 2007. "Cyberspace Classification and Cognition: Information Communications Cyberspace", Journal of Urban Technology, Vol. 14, No. 3. https://doi. org/10.1080/10630730801923110.

Muttaqin, Ahmad. 2012. "Agama dalam Representasi Ideologi Media Massa", Jurnal Komunika: Jurnal Dakwah dan Komunikasi, Vol. 6, No. 2.

Piliang, Yasraf Amir. 2010, Dunia Yang Dilipat: Tamasya Melampaui BatasBatas Kebudayaan. Bandung: Matahari.

Suharto, Babun. 2019. Moderasi Beragama: Dari Indonesia untuk Dunia. Yogyakarta: LKiS.

Sukowati, Muria Endah. 2015. Agama, Media dan Pemasaran dalam Masyarakat Majemuk. Yogyakarta: Litera.

Tim Balitbang Kemenag RI, 2019. Moderasi Beragama (Jakarta: Badan Litbang dan Diklat Kementerian Agama RI.

Virilio, Paul. 1989. “The Last Vehicle”, dalam Dietmar Kamper \& Christoph Wulf, Looking Back on The End of World. Semiotext.

Zulkifli, 2013. "The Ulama in Indonesia: Between Religious Authority and Symbolic Power", Jurnal Miqot, Vol. XXXII, No. 1. 


\section{Endnotes}

1. Tim Balitbang Kemenag RI, Moderasi Beragama (Jakarta: Badan Litbang dan Diklat Kementerian Agama RI, 2019), 47.

2. Paul Virilio, "The Last Vehicle", dalam Dietmar Kamper \& Christoph Wulf, Looking Back on The End of World (Semiotext, 1989), 108.

3. Heidi Campbell, When Religion Meets New Media (London: Routledge, 2010), 24.

4. Zulkifli, "The Ulama in Indonesia: Between Religious Authority and Symbolic Power", Jurnal Miqot, Vol. XXXII, No. 1 (2013), 179.

5. Ahmad Muttaqin, "Agama dalam Representasi Ideologi Media Massa", Jurnal Komunika: Jurnal Dakwah dan Komunikasi, Vol. 6, No. 2 (2012).

6. Edaran Direktur Jenderal Pendidikan Islam Kementerian Agama RI Nomor B-3663.1/Dj.I/BA.02/10/2019 tentang Rumah Moderasi Beragama tanggal 29 Oktober 2019.

7. Tim Balitbang Kemenag RI, Moderasi Beragama (Jakarta: Badan Litbang dan Diklat Kementerian Agama RI, 2019), 16.

8. Mohammad Hasyim Kamali, The Middle Path of Moderation in Islam: The Qur'anic Principle of Wasathiyah (Oxford: Oxford University Press, 2015), 31.

9. Tim Balitbang Kemenag RI, Moderasi Beragama, 20.

10. Busro, "Moderasi Islam (Wasatiyyah) di Tengah Pluralisme Agama di Indonesia", Fuaduna: Jurnal Kajian Keagamaan dan Kemasyarakatan, Vol. 3, No. 1 (2019), 10.

11. Babun Suharto, Moderasi Beragama: Dari Indonesia untuk Dunia (Yogyakarta: LKiS, 2019), 7.

12. Babun Suharto, Moderasi Beragama, 13.

13. Babun Suharto, Moderasi Beragama, 15.

14. Yasraf Amir Piliang, Dunia Yang Dilipat: Tamasya Melampaui Batas-Batas Kebudayaan (Bandung: Matahari, 2010), 111.

15. Aharon Kellerman, “Cyberspace Classification and Cognition: Information Communications Cyberspace", Journal of Urban Technology, Vol. 14, No. 3 
(2007), 31. https://doi.org/10.1080/10630730801923110.

16. David Harvey, The Condition of Postmodernity: An Inquiry into The Origins of Cultural Change (Cambridge: Blackwell Publisher, 1990), 240.

17. Yasraf Amir Piliang, Dunia Yang Dilipat, 65.

18. Mutohharun Jinan, "Intervensi New Media dan Impersonalitas Otoritas Keagamaan", Jurnal Komunikasi Islam, Vol. 3, No. 2, (Desember, 2013), 323. https://doi.org/10.15642/jki.2013.3.2.\%25p

19. Rizqa Ahmadi, “Kontestasi Atas Otoritas Teks Suci Islam di Era Disrupsi: Bagaimana Kelas Menengah Muslim Indonesia Memperlakukan Hadis Melalui Media Baru", Jurnal Studi Agama dan Masyarakat, Vol. 15, No. 1 (2019), 25. https://doi.org/10.23971/jsam.v15i1.1138

20. Lorne Dawson, "Researching Religion in Cyberspace: Issues and Strategies" dalam Religion on the Internet: Research Prospects and Promises, Religion and the Social Order, Volume 8, ed Jeffery Hadden dan Douglas Cowan, (New York: JAI Press, 2000), 43.

21. Rizqa Ahmadi, "Kontestasi Atas Otoritas Teks Suci Islam di Era Disrupsi", 29.

22. Post-truth dalam ruang digital ditandai dengan masifnya semburan dusta (firehose of false) yang menyeret dalam dark social (kegelapan sosial) yang kemudian berdampak pada kedengkian dan permusuhan. Steve Fuller, Post Truth: Knowledge as Power Game (London: Anthem Press, 2018), 7.

23. Rizqa Ahmadi, "Kontestasi Atas Otoritas Teks Suci Islam di Era Disrupsi”, 29.

24. Muria Endah Sukowati, Agama, Media dan Pemasaran dalam Masyarakat Majemuk (Yogyakarta: Litera, 2015), 3.

25. Yasraf Amir Piliang, Dunia Yang Berlari: Dromologi, Implosi, Fantasmagoria (Yogyakarta: Cantrik Pustaka, 2017), 159.

26. Martin Heidegger, "The Question Concerning Technology", dalam Basic Writings (San Francisco: Harper, 1971), 149.

27. Mihaly Csikszenthimaly, The Evolving Self: A Psychology for the Third Millenium (Harper: Parennial, 1993), 120.

28. Yasraf Amir Piliang, Dunia Yang Dilipat, 93. 